\title{
Relationships between genetic polymorphism and herbicide resistance within Alopecurus myosuroides Huds.
}

\author{
BRUNO CHAUVEL* \& JACQUES GASQUEZ \\ I.N.R.A., Laboratoire de Malherbologie, B.V. 1540, 21034 Dijon Cédex, France
}

\begin{abstract}
The genetic structure of a gramineous weed (Alopecurus myosuroides Huds.) was investigated by an electrophoretic survey of seven enzyme systems on 19 susceptible and herbicide-resistant populations collected in different countries. The results indicate that Alopecurus myosuroides is an allogamous self-incompatible plant with a high level of genetic polymorphism (60 per cent of loci polymorphic, average heterozygosity $=0.21$ ) and with a very low genetic differentiation among populations (Nei's distances less than 0.06) from wide geographical origins. A comparison of expected and observed levels of heterozygosity indicates no significant departure from random mating. Furthermore, there is no evidence of differences between resistant and susceptible populations in any genetic parameter. This is the first example of no change in genetic structure within resistant weed populations after herbicide selection.
\end{abstract}

Keywords: Alopecurus myosuroides, genetic polymorphism, herbicide resistance, isozymes, mating system, weed.

\section{Introduction}

One of the consequences of increasing pesticide use against pest species is the development of resistant populations. This has occurred in fungi (Leroux, 1987), insects (Georghiou, 1990), mammals (Bishop et al., 1977) and flowering plant weeds (Darmency \& Gasquez, 1990). More than 80 resistant weed species have already been described (Lebaron, 1991). Almost all chemical herbicide groups have generated a resistance response in weed populations, either by target mutation or by detoxification. The resistant biotypes may invade a field within 5 years or less (MallorySmith et al., 1990). Resistant populations provide extremely good models for the processes of rapid evolution under strong selection pressures.

Alopecurus myosuroides Hudson (black-grass or slender foxtail) is a serious annual winter weed in north Europe where field conditions (farming methods, monoherbicide use) have led to the development of resistant populations. Resistance to several herbicides has been reported. Populations resistant to chlorotoluron (substituted ureas herbicide) have been observed in the U.K. (Moss \& Cussans, 1985), in Germany (Niemann \& Pestemer, 1984) and in Spain (de Prado et

\footnotetext{
*Correspondence.
}

al., 1991). The mechanism of resistance, at least in the British populations, is detoxification of the herbicide by non-specific cytochrome P-450 monooxygenase enzymes (Caseley et al., 1990). This mechanism is nuclearly inherited and controlled by several genes (Chauvel, 1991); thus a resistant plant produces mixed susceptible and resistant progenies. Triazine-resistant populations have appeared in Czechoslovakia (Mikulka, 1987) and Israel (Yaacoby et al., 1986). Here resistance is due to mutation in the chloroplast DNA encoding the herbicide target as already described for many other species (McNally et al., 1987) and as for all the triazine-resistant species, all the progeny of a resistant plant are resistant (Darmency \& Gasquez, 1990). In addition, a resistance to fenoxaprop-P-ethyl has been recently selected in greenhouse plants (Chauvel et al., 1992). Thus Alopecurus myosuroides is a good species in which to study the genetic evolution of population structure under selection by different herbicides.

The general effect of farming is to reduce the variability in weed species (Warwick, 1991a). For example, selection for triazine resistance can lead to a significant decrease in polymorphism (Al Mouemar \& Gasquez, 1983; Warwick \& Black, 1986). Similar results have been found within resistant insect populations (Georghiou, 1990).

There are, however, relatively few studies on resistant populations and none on species resistant to more 
than one herbicide. The study of resistant black-grass populations enables a comparison of genetic evolution in the same species of herbicide resistances with different modes of inheritance (triazine resistance is maternally inherited (Darmency \& Gasquez, 1990) and at least two nuclear genes encode for chlorotoluron resistance (Chauvel, 1991)). The aim of this work is to describe the genetic structure of populations of the weed and to investigate the genetic consequences of the occurrence of two separate and genetically independent resistance mechanisms (detoxification and target mutation) within the same species. The pattern of genetic variability as revealed by isozyme variation within and between susceptible and resistant populations from different geographical origins is determined to check whether the selection of resistance genes is linked to a change in the genetic structure of the resistant populations. We also hope to gain insight into the effect of an outcrossing mating system on the evolution of resistant weed populations.

\section{Materials and methods}

\section{Origin of populations}

Nineteen populations were sampled from a wide range of agricultural conditions in France, the U.K., Germany and Israel (Table 1). Nine populations (F1-F9) were collected in fields around Dijon in the Burgundy district of eastern France. These were all susceptible to all herbicides. Seeds collected in fields in Essex and Oxfordshire, where resistant plants have been observed (Moss \& Cussans, 1985) correspond to English resistant populations G1, G2 and G3. Population G4 is a seed sample collected in a field at Rothamsted that has never been treated with herbicides (Moss \& Cussans, 1985). As we have previously shown that the resistant populations were composed of susceptible and resistant plants (Chauvel, 1991), the populations G5 and G6 were selected from G1 and G2, respectively, by chlorotoluron treatments or fluorescence test. Two populations have been collected in Israel: one (I1) resistant, the other (I2) susceptible to triazines (Yaacoby et al., 1986).

\section{Methods}

Foliar isoenzymes were separated by electrophoresis on a polyacrylamide gel using the method described by Ornstein (1964) and Gasquez \& Compoint (1981) in a discontinuous system with pulsed power.

Enzyme extracts were obtained from leaves of 2-month-old plants grown in the greenhouse at $16 \mathrm{~h}$ light $\left(20^{\circ} \mathrm{C}, 250 \mu \mathrm{E} \mathrm{m}^{-2}\right.$ per second $)$ and $8 \mathrm{~h}$ dark $\left(10^{\circ} \mathrm{C}\right)$. Four enzymes, glutamic-oxaloacetic transaminase (GOT, E.C. 2.6.1.1), superoxide dismutase (SOD, E.C. 1.15.1.1), leucine amino peptidase (LAP, E.C. 3.4.11.1), acid phosphatase (ACP, E.C. 3.1.3.2), have been studied. Detailed specifications of laboratory techniques are given in Lumaret (1981) and in Chauvel (1991).

Analyses of the data have been performed using the computer program for analysis of allelic variation BIOsYs-1 (release 1.7). A set of standard genetic parameters has been calculated: average heterozygosity, Nei's unbiased distance, $F$-statistics. Formulae and references are given in Swofford \& Selander (1981). We have also calculated Marshall's index $H$ (Marshall \& Allard, 1970) and the estimator of the variance for this index $E_{V}$ (Zhang \& Allard, 1986).

$H=\left(\sum_{l=1}^{n} \sum_{i \neq j}^{k l} p_{l i} * p_{l j}\right) / n$,

where $p_{l i}=$ the frequency of the $i$ th allele at the $l$ th locus, $p_{l j}=$ the frequency of the $j$ th allele at the $l$ th locus, $k=$ the total number of alleles and $n=$ the total number of loci.

$E_{v}=\frac{1}{n(n-1)} * \sum_{i=1}^{k}\left(h_{l}-H\right)^{2}$

where $n=$ the total number of loci, $H=$ the average diversity per locus and $h_{l}=$ the diversity of the $l$ th locus.

\section{Results}

Only enzyme systems with enough resolution to enable reliable interpretation have been used. The genetic variation in these systems and diagrams of the bands are given in Chauvel (1991). A total of 31 bands has been distinguished for the four enzymes GOT, LAP, $\mathrm{ACP}$ and SOD.

\section{Allelic frequencies}

The loci were numbered 1 and 2 in order of distance, locus 1 being nearer the origin (the slower migrating). The 31 bands are governed by eight loci ( 24 alleles, seven heterodimeric bands), whose characteristics are summarized in Table 2. Locus SODI is always monomorphic (only one allele) and is not considered further. Locus GOT2 is only variable in Israeli populations (Table 3). Some other rare alleles at $L A P 2, A C P 2$ and GOT1 appear only for Israeli plants. The study of allozyme patterns at $L A P 2$ revealed a low frequency $(1-5$ per cent) of a null-allele within seven of the French 
Table 1 Populations sampled in this study

\begin{tabular}{|c|c|c|c|c|c|}
\hline Population $\dagger$ & Site: $N(\mathrm{p})$ & Year & Origin & Culture conditions & Sampling \\
\hline F1 & $\begin{array}{l}\text { Bretenières } 1 \\
\quad(130)\end{array}$ & 1978 & Wheat & Winter germination, basic soil & Seeds \\
\hline $\mathrm{F} 2$ & $\begin{array}{l}\text { Epoisses } \\
(130)\end{array}$ & 1984 & Barley & Spring germination, basic soil & Seeds \\
\hline F3 & $\begin{array}{l}\text { Labergement } \\
\qquad(130)\end{array}$ & 1985 & Barley & Winter germination, basic soil & Seeds \\
\hline F4 & $\begin{array}{l}\text { Longvic } \\
(130)\end{array}$ & 1987 & Fallow & Summer germination, basic soil & Seeds \\
\hline F5 & $\begin{array}{l}\text { Bretenières } 2 \\
\quad(130)\end{array}$ & 1988 & Onions & Winter germination, basic soil & Seedlings \\
\hline F6 & $\begin{array}{l}\text { Aubigny } \\
(113)\end{array}$ & 1988 & Fallow & Winter germination, basic soil & Seedlings \\
\hline F7 & $\begin{array}{l}\text { Ouges } \\
(114)\end{array}$ & 1988 & Pea & Spring germination, basic soil & Seedlings \\
\hline F8 & $\begin{array}{l}\text { Bagnot } 1 \\
(130)\end{array}$ & 1988 & Wheat & Winter germination, acid soil & Seeds \\
\hline F9 & $\begin{array}{l}\text { Bagnot } 2 \\
(130)\end{array}$ & 1988 & Oat & Spring germination, acid soil & Seeds \\
\hline G1 & $\begin{array}{l}\text { Peldon A } \\
\quad(79)\end{array}$ & 1984 & Wheat & $\begin{array}{l}\text { Winter germination surviving } \\
\text { chlorotoluron treatment }\end{array}$ & Seeds \\
\hline G2 & $\begin{array}{l}\text { Peldon B } \\
(130)\end{array}$ & 1987 & Wheat & $\begin{array}{l}\text { Winter germination surviving } \\
\text { chlorotoluron treatment }\end{array}$ & Seeds \\
\hline G3 & $\begin{array}{l}\text { Farringdon } \\
\quad(130)\end{array}$ & 1987 & Wheat & $\begin{array}{l}\text { Winter germination surviving } \\
\text { chlorotoluron treatment }\end{array}$ & Seeds \\
\hline G4 & $\begin{array}{l}\text { Rothamsted } \\
\quad(130)\end{array}$ & 1987 & Wheat & $\begin{array}{l}\text { Winter germination } \\
\text { Susceptible to chlorotoluron }\end{array}$ & Seeds \\
\hline G5 & $\begin{array}{l}\text { Resistant A } \\
\quad(63)\end{array}$ & 1988 & - & $\begin{array}{l}\text { Progenies of G1 } \\
\text { Resistant to chlorotoluron }\end{array}$ & Seeds \\
\hline G6 & $\begin{array}{l}\text { Resistant B } \\
\quad(84)\end{array}$ & 1988 & - & $\begin{array}{l}\text { Sample to G2 } \\
\text { Resistant to chlorotoluron }\end{array}$ & Seeds \\
\hline A1 & $\begin{array}{l}\text { Sommerland } \\
(130)\end{array}$ & 1983 & Wheat & $\begin{array}{l}\text { Winter germination surviving } \\
\text { chlorotoluron treatment }\end{array}$ & Seeds \\
\hline $\mathrm{A} 2$ & $\begin{array}{l}\text { Braunschweig } \\
\quad(130)\end{array}$ & 1983 & Wheat & $\begin{array}{l}\text { Winter germination } \\
\text { Susceptible to chlorotoluron }\end{array}$ & Seeds \\
\hline I1 & $\begin{array}{c}\text { Yyzreel Valley } \\
(130)\end{array}$ & 1986 & Road side & $\begin{array}{l}\text { Winter germination } \\
\text { Resistant to triazines }\end{array}$ & Seeds \\
\hline I2 & $\begin{array}{l}\text { Newe Yaar Station } \\
(130)\end{array}$ & 1986 & Wheat & $\begin{array}{l}\text { Winter germination } \\
\text { Susceptible to triazines }\end{array}$ & Seeds \\
\hline
\end{tabular}

$N(\mathrm{p})$ : sample size.

†Country of origin: Fn, France; Gn, U.K.; An, Germany; In, Israel.

populations; we postulated that this allele exists only in the homozygous state. All frequencies of the seven loci for the 19 populations are summarized in Table 3 . It is noticeable that the loci, except for SOD2 in the European populations, have a major allele with a frequency ranging from 75 per cent to 95 per cent and some rare alleles with frequencies around 10 per cent. The comparison of the allelic frequencies by $\chi^{2}$ or G tests (test of homogeneity at $P \leq 5$ per cent; data not shown) indicates that the frequency distributions can be dissimilar for a locus among the 19 populations; Israeli popula- tions differ from the others in $S O D 2$ allelic frequencies, German populations at the $A C P 2$ locus. There is, however, no relationship between the presence or the absence of any allele and resistant or susceptible populations whatever the resistance; no allele or allelic frequency could be used as a resistance marker.

\section{Intrapopulation variability}

The intrapopulation variability of black-grass is estimated by the number of alleles per locus ( 2.2 to 3.3 , 
Table 2 Characteristics of the observed loci

\begin{tabular}{llcccc}
\hline \multirow{2}{*}{ Enzyme } & Loci & Alleles & $\begin{array}{c}\text { Relative } \\
\text { mobility }\end{array}$ & Structure & Remarks \\
\hline \multirow{2}{*}{ GOT } & GOT1 & 4 & $0.13-0.19$ & Dimeric & - \\
& GOT2 & 3 & $0.39-0.43$ & Dimeric & Only in I1 and 12 \\
LAP & LAP1 & 3 & $0.30-0.34$ & Monomeric & - \\
& LAP2 & 5 & $0.40-0.46$ & Monomeric & - \\
ACP & ACP1 & 2 & $0.35-0.37$ & Monomeric & Not read in I1 and I2 \\
& ACP2 & 4 & $0.42-0.48$ & Dimeric & - \\
SOD & SOD1 & 1 & 0.50 & Not studied & Monomorphic \\
& SOD2 & 2 & $0.68-0.76$ & Dimeric & - \\
\hline
\end{tabular}

mean 2.45), the number and the percentage of polymorphic loci (more than 70 per cent) and by the total mean heterozygosity in all populations (about 0.209 ). These values are close to the values given by Hamrick et al. (1979), Gottlieb (1981) and Loveless \& Hamrick (1984) for a polymorphic allogamous species (Table 4). The value of the mean heterozygosity indicates that there is no significant departure from Hardy-Weinberg equilibrium (Table 4). The mean heterozygosity always shows fewer heterozygous plants than expected, even though the difference is not statistically significant.

Analysis of population structure was conducted with the $F$-statistics listed in Table 5. The $F_{\text {is }}$ index (fixation index of individuals within the populations) has a high mean value $(0.176)$ which confirms the deficiency of heterozygotes observed with LAP and ACP enzymes. But the low mean value $(0.023)$ of $F_{\text {st }}$ (fixation index among populations) indicates a panmictic structure. $F$ statistic values show a high level of differentiation within the populations and a very low variability between populations. It is impossible to distinguish resistant from susceptible populations in terms of either allelic diversity (alleles per locus), heterozygosity or percentage of polymorphic loci.

\section{Interpopulation variability}

The interpopulation genetic diversity can be estimated by using the Marshall index on six loci. The population A2 has the lowest diversity index. Israeli populations have a genetic diversity lower than European populations due to the locus SOD2 (Table 6) but standard errors indicate that the differences between geographical areas are not statistically significant.

Genetic distance between each pair of populations is very low: $0.000-0.013$ within the European popula- tions and $0.000-0.058$ with the Israeli populations included. These two last populations are very similar, despite the fact that I1 and I2 are resistant and susceptible to triazines, respectively. The average genetic distances (cluster analysis) between all populations revealed no important separation (Fig. 1). The clustering level of the European populations is very low $(0.00612)$. Only the Israeli populations show a differentiation due to their specific rare alleles (clustering level: 0.0404 ) but the frequency of these alleles is not enough to distinguish statistically the Mediterranean populations. Whatever the genetic index used, the calculated values reveal no statistical separation between the French (F), English (G), German (A) and Israeli (I) populations.

\section{Polymorphism and resistance}

The values of the Marshall diversity index for chlorotoluron-resistant populations are very similar to the values of the susceptible populations (Table 6). In the same way, values of susceptible and triazine-resistant populations are not statistically different. Furthermore, herbicide-resistant populations are not close in the cluster analysis (Fig. 1); susceptible and resistant populations from the same geographical area show no genetic differentiation. Naturally resistant populations (G1, G2 and G3) and selected progenies (G5 and G6) are similar to the English susceptible population G4. There is no level of cluster, even very low, which enables a distinction to be made between the chlorotoluron-resistant populations from Germany or the U.K. It seems that the development of a resistance mechanism did not lead to genetic differentiation or to a change in the genetic structure of the resistant populations in comparison with the susceptible ones. 
Table 4 Parameters of genetic variability at eight loci within 19 populations

\begin{tabular}{|c|c|c|c|c|c|}
\hline \multirow[b]{2}{*}{ Population } & \multirow[b]{2}{*}{$N(\mathbf{p})$} & \multirow[b]{2}{*}{$N(1)$} & \multirow[b]{2}{*}{ Perc. } & \multicolumn{2}{|c|}{ Average heterozygosity } \\
\hline & & & & Observed & Expected \\
\hline $\mathrm{F} 1$ & 130 & $\begin{array}{c}2.5 \\
(0.4)\end{array}$ & 75.0 & $\begin{array}{c}0.213 \\
(0.071)\end{array}$ & $\begin{array}{c}0.283 \\
(0.077)\end{array}$ \\
\hline $\mathrm{F} 2$ & 130 & $\begin{array}{c}2.3 \\
(0.3)\end{array}$ & 75.0 & $\begin{array}{c}0.208 \\
(0.075)\end{array}$ & $\begin{array}{c}0.256 \\
(0.075)\end{array}$ \\
\hline F3 & 130 & $\begin{array}{c}2.5 \\
(0.4)\end{array}$ & 75.0 & $\begin{array}{c}0.221 \\
(0.086)\end{array}$ & $\begin{array}{c}0.278 \\
(0.078)\end{array}$ \\
\hline $\mathrm{F} 4$ & 130 & $\begin{array}{c}2.5 \\
(0.4)\end{array}$ & 75.0 & $\begin{array}{c}0.210 \\
(0.090)\end{array}$ & $\begin{array}{c}0.252 \\
(0.078)\end{array}$ \\
\hline F5 & 130 & $\begin{array}{c}2.5 \\
(0.4)\end{array}$ & 75.0 & $\begin{array}{c}0.228 \\
(0.076)\end{array}$ & $\begin{array}{c}0.282 \\
(0.081)\end{array}$ \\
\hline F6 & 113 & $\begin{array}{c}2.5 \\
(0.4)\end{array}$ & 75.0 & $\begin{array}{c}0.223 \\
(0.075)\end{array}$ & $\begin{array}{c}0.277 \\
(0.070)\end{array}$ \\
\hline F7 & 114 & $\begin{array}{c}2.5 \\
(0.4)\end{array}$ & 75.0 & $\begin{array}{c}0.199 \\
(0.068)\end{array}$ & $\begin{array}{c}0.274 \\
(0.074)\end{array}$ \\
\hline F8 & 130 & $\begin{array}{c}2.5 \\
(0.4)\end{array}$ & 75.0 & $\begin{array}{c}0.201 \\
(0.066)\end{array}$ & $\begin{array}{c}0.269 \\
(0.086)\end{array}$ \\
\hline F9 & 130 & $\begin{array}{c}2.3 \\
(0.3)\end{array}$ & 75.0 & $\begin{array}{c}0.240 \\
(0.066)\end{array}$ & $\begin{array}{c}0.279 \\
(0.086)\end{array}$ \\
\hline G1 & 130 & $\begin{array}{c}2.3 \\
(0.3)\end{array}$ & 75.0 & $\begin{array}{c}0.228 \\
(0.081)\end{array}$ & $\begin{array}{c}0.279 \\
(0.074)\end{array}$ \\
\hline G2 & 130 & $\begin{array}{c}2.3 \\
(0.3)\end{array}$ & 75.0 & $\begin{array}{c}0.221 \\
(0.067)\end{array}$ & $\begin{array}{c}0.277 \\
(0.079)\end{array}$ \\
\hline G3 & 130 & $\begin{array}{c}2.3 \\
(0.3)\end{array}$ & 75.0 & $\begin{array}{c}0.235 \\
(0.067)\end{array}$ & $\begin{array}{c}0.271 \\
(0.076)\end{array}$ \\
\hline G4 & 130 & $\begin{array}{c}2.3 \\
(0.3)\end{array}$ & 75.0 & $\begin{array}{c}0.227 \\
(0.067)\end{array}$ & $\begin{array}{c}0.252 \\
(0.098)\end{array}$ \\
\hline G5 & 63 & $\begin{array}{c}2.3 \\
(0.3)\end{array}$ & 62.5 & $\begin{array}{c}0.209 \\
(0.086)\end{array}$ & $\begin{array}{c}0.261 \\
(0.080)\end{array}$ \\
\hline G6 & 84 & $\begin{array}{c}2.3 \\
(0.3)\end{array}$ & 75.0 & $\begin{array}{c}0.202 \\
(0.069)\end{array}$ & $\begin{array}{c}0.263 \\
(0.087)\end{array}$ \\
\hline A1 & 130 & $\begin{array}{c}2.2 \\
(0.3)\end{array}$ & 62.5 & $\begin{array}{c}0.213 \\
(0.075)\end{array}$ & $\begin{array}{c}0.196 \\
(0.071)\end{array}$ \\
\hline A2 & 130 & $\begin{array}{c}2.2 \\
(0.3)\end{array}$ & 62.5 & $\begin{array}{c}0.168 \\
(0.074)\end{array}$ & $\begin{array}{c}0.240 \\
(0.077)\end{array}$ \\
\hline I1 & 130 & $\begin{array}{c}3.0 \\
(0.4)\end{array}$ & 71.4 & $\begin{array}{c}0.183 \\
(0.052)\end{array}$ & $\begin{array}{c}0.240 \\
(0.077)\end{array}$ \\
\hline $\mathrm{I} 2$ & 130 & $\begin{array}{c}3.3 \\
(0.3)\end{array}$ & 85.7 & $\begin{array}{c}0.140 \\
(0.031)\end{array}$ & $\begin{array}{c}0.227 \\
(0.068)\end{array}$ \\
\hline Mean values & - & 2.45 & 73.4 & 0.209 & - \\
\hline
\end{tabular}

$N(\mathrm{p})$ : mean sample size per population; $N(1)$ : mean number of alleles per locus; Perc.: percentage of loci polymorphic (calculated on 7 loci for the Israeli populations); for average heterozygosity, standard errors (in brackets) are calculated at $P=5 \%$.

\section{Discussion}

Weed species are good models for the study of genetic selection because their evolution under very strong herbicide modification pressure (more than 90 per cent
Table $5 F$-statistics values of $F_{\text {is }}, F_{\text {it }}$ and $F_{\text {st }}, F_{\text {is }}$ and $F_{\text {it }}$ are, respectively, the fixation index of individuals within populations and relative to the total of the populations. $F_{\mathrm{st}}$ measures the amount of differentiation among populations

\begin{tabular}{lrrr}
\hline Locus & \multicolumn{1}{c}{$F_{\text {is }}$} & \multicolumn{1}{c}{$F_{\text {it }}$} & \multicolumn{1}{c}{$F_{\text {st }}$} \\
\hline GOT1 & 0.052 & 0.062 & 0.011 \\
GOT2 & 0.223 & 0.248 & 0.031 \\
SOD1 & -0.084 & -0.009 & 0.069 \\
$A C P 1 \dagger$ & 0.113 & 0.121 & 0.009 \\
$A C P 2$ & 0.106 & 0.118 & 0.013 \\
$L A P 1$ & 0.478 & 0.485 & 0.013 \\
$L A P 2$ & 0.347 & 0.358 & 0.017 \\
Mean & 0.176 & 0.197 & 0.023 \\
\hline
\end{tabular}

$†$ Not calculated on the Israeli populations.

Table 6 Marshall index values and standard errors at $P=5 \%$ calculated on GOT, $L A P, S O D$ and $A C P 2$

\begin{tabular}{cc}
\hline Populations & Marshall index \pm S.E. \\
\hline F1 & $0.2812 \pm 0.150$ \\
F2 & $0.2513 \pm 0.147$ \\
F3 & $0.2770 \pm 0.153$ \\
F4 & $0.2511 \pm 0.153$ \\
F5 & $0.2813 \pm 0.159$ \\
F6 & $0.2759 \pm 0.137$ \\
F7 & $0.2731 \pm 0.145$ \\
F8 & $0.2674 \pm 0.168$ \\
F9 & $0.2917 \pm 0.167$ \\
G1 & $0.2774 \pm 0.167$ \\
G2 & $0.2777 \pm 0.144$ \\
G3 & $0.2762 \pm 0.155$ \\
G4 & $0.2700 \pm 0.149$ \\
G5 & $0.2504 \pm 0.190$ \\
G6 & $0.2589 \pm 0.157$ \\
A1 & $0.2618 \pm 0.171$ \\
A2 & $0.1875 \pm 0.140$ \\
I1 & $0.2386 \pm 0.150$ \\
I2 & $0.2261 \pm 0.132$ \\
\hline
\end{tabular}

of mortality after each treatment) is obvious in a few generations. We have shown that Alopecurus myosuroides is allogamous (as was assumed by Johnsson (1944), Menck (1968) and Naylor (1972) on the basis of its flowering characteristics, wind-pollination and protogynous flowers). We have previously shown that the percentage of viable seeds after enforced self-fertilization is very low (partial selfincompatibility, Chauvel, 1991). Furthermore, levels of genetic variation are those expected with an outbreeding mating system as in this species. The number of 


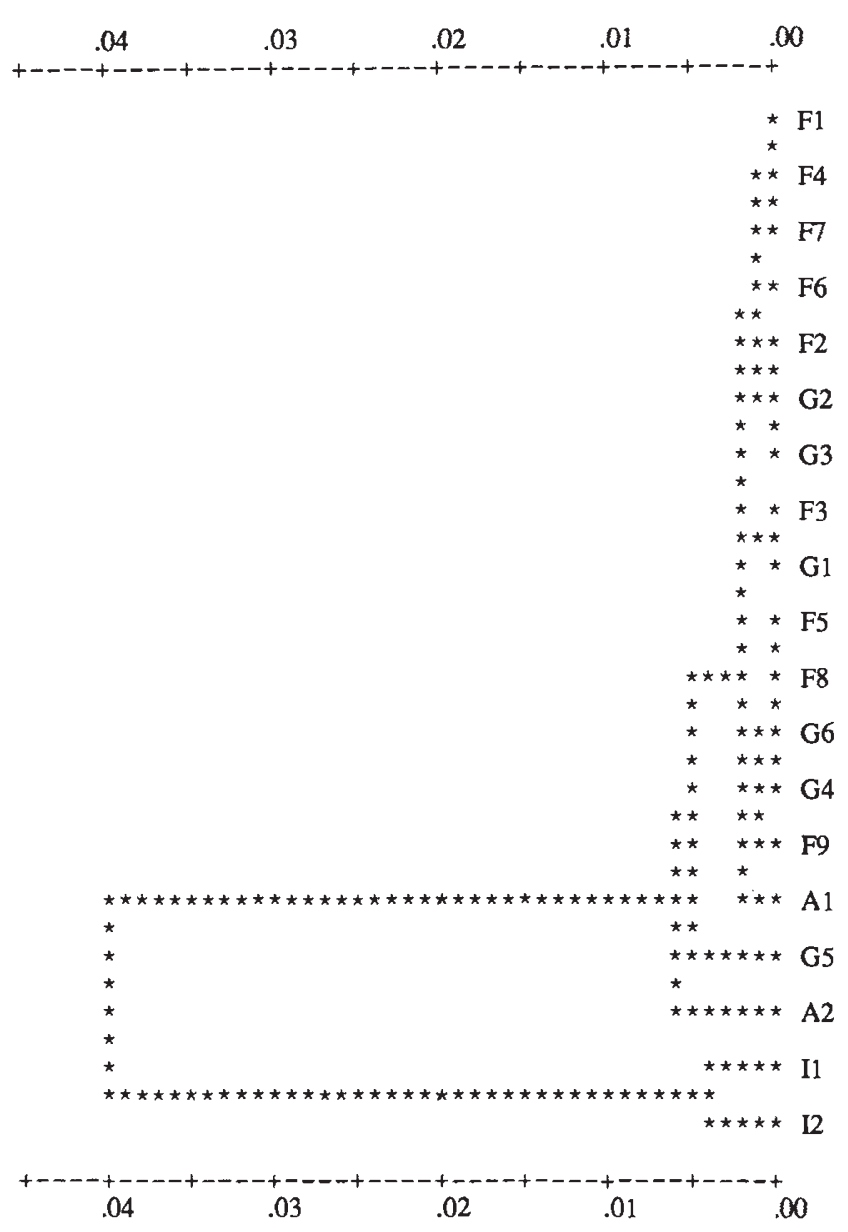

Fig. 1 Phenogram showing the relationships of the 19 populations by a cluster analysis using Nei's unbiased genetic distance.

alleles (about 2.2), the percentage of polymorphic loci (more than 60 per cent) and the average heterozygosity (about 0.21) are similar to those described for many allogamous species in the literature (Brown, 1979). The index values we obtained are almost identical to those described for Apera spica-venti, a weed ecologically close to black-grass (Warwick et al., 1987). The level of genetic variation in black-grass populations is in accordance with the results generally observed for an outcrossing species: high variability and reduced divergence between populations due to pollen flow (Hamrick et al., 1979; Loveless \& Hamrick, 1984). The results of this study match also the high level of polymorphism observed in the morphological characteristics of black-grass: leaf area, spikelet size, tillers and anther colour (Menck, 1968; Naylor, 1972). The deficit of heterozygosity observed at three loci ( $L A P 1, L A P 2, A C P 2$ ) is also often observed in outbreeding species (described by Brown (1979) as the heterozygosity paradox).
Furthermore, the studied loci have almost the same structure: a major allele (about 85 per cent) and two, three or four rare alleles according to the locus. Only the locus SOD2 has frequencies of 55 per cent and 45 per cent for each allele, respectively. This allelic structure could explain the heterozygous deficiency which could also be due to temporal structuring (the seed banks contain seeds of different generations) or spatial structure at the field scale. We have shown that more than 70 per cent of the pollen dispersal occurs within $1 \mathrm{~m}$ (Chauvel, 1991). So the field (limit of our sample) could include several subpopulations. If we consider the mean heterozygosity calculated for the seven loci, black-grass populations fit with panmixia equilibrium: it seems that genes are mostly exchanged at random within a field. This may reflect the effects of a crop rotation system, farming methods distributing seed around the whole field. Thus the boundaries of the field could correspond to the limit of the effective population.

As for all the sampled populations, the very low clustering level of the dendrogram based on Nei's genetic distance revealed no separation of the different geographical populations, even for the Israeli group. We have also already shown that these populations have the same major phenotypes at similar frequencies (Chauvel \& Gasquez, 1988). There is little phenotypic variability among populations and the small differences are not connected with geographical origin or resistance. Low genetic differentiation is not due to a lack of polymorphism but to similar levels of intrapopulation variability.

Studies of genetic variation of weeds (and invaders generally) after their introduction (Warwick et al., 1987) in a new geographical area have shown that an outcrossing mating system reduces the effect of genetic drift in comparison with a strong inbreeding mating system (Warwick, 1991a; Bosbach \& Hurka, 1981). As for black-grass, only constant gene exchanges by pollen dispersal (close populations) or by seeds (distant populations) with crops could explain such identical frequencies among populations. Thus, the low genetic differentiation among populations of wide geographical origin is not easy to explain because the population distribution is discontinuous and because black-grass grows only in winter cereals. Furthermore, the populations of this weed are not as large as in the past and black-grass has been regarded as a serious weed only in recent years (Naylor, 1972).

The genetic polymorphism of populations subjected to a high herbicide selection pressure is generally reduced because of the low number of surviving plants. These results have been shown already within resistant fungi and insect populations (Leroux, 1987; 
Georghiou, 1990). The same results have been found for predominantly autogamous triazine-resistant weeds, such as Amaranthus retroflexus (Warwick \& Black, 1986). Within an allogamous species, Chenopodium album, it has been shown by Al Mouemar \& Gasquez (1983) that the rate of phenotypic polymorphism is very high in gardens, reduced in treated fields and reduced to only one phenotype in the triazine-resistant populations. Recent results have shown that within an allogamous weed (Brassica rapa), the triazine-resistant populations have only a slightly reduced genetic variability (Warwick \& Black, 1993).

Within Alopecurus myosuroides, we have not found any genetic difference between susceptible and triazine-resistant populations. On the other hand, if we consider chlorotoluron resistance, populations $\mathrm{G} 1, \mathrm{G} 2$ and G3 have been grown from seeds harvested on field surviving plants. We have shown that their progenies still contained high frequencies of susceptible plants. The samples G5 and G6 have been selected by laboratory herbicide treatment or by a fluorescence test. In all cases we found no significant genetic differences between the resistant and the susceptible plants, even in the population $\mathrm{G} 4$ which has never been treated with chlorotoluron. Furthermore, we have previously shown that the plants surviving treatments show different resistance levels corresponding to the presence of different resistant biotypes (Chauvel, 1991). As the species is highly allogamous, most of the surviving plants are heterozygous for almost all the characters. Thus each year, plants heterozygous for resistance survive the treatments and produce susceptible genotypes within their progeny. The genetic identity observed could be explained by continuous genetic exchanges between resistant and susceptible plants favoured by allogamy within progenies of surviving plants. As the chlorotoluron resistance is a polygenically inherited mechanism (Chauvel, 1991) it is possible that independent resistance genes have spread for a long time within 'wild' populations before herbicide treatments. As we have previously shown that there is no significant difference in the fitness of susceptible and resistant biotypes (Chauvel, 1991), we can assume that these genes are randomly distributed within the genotypes so that the plants surviving the herbicide would be a statistical sample of each population.

The first results on resistant weed populations were obtained for chloroplastic-triazine resistance. The cytoplasmic monogenic inheritance and the mechanism of this resistance explain to a great extent the characteristics generally observed within resistant populations: reduced genetic variability and lower fitness, respectively (Warwick, 1991b). Our data on Alopecurus myosuroides are the first results on a weed with a polygenically inherited resistance mechanism due to a detoxification. These characteristics lead to peculiar consequences: no mutation cost and reduced spreading ability of resistant biotypes. Such a case has not been generally examined in the previous models predicting resistance development (Warwick, 1991b). Therefore, from a genetic point of view, chlorotoluron resistance outcomes are different from other resistances: there is no invasion of resistant black-grass in cereal fields as for triazine-resistant Chenopodium album biotypes in maize fields (Gasquez, 1985) or of resistant insect populations (Georghiou, 1990). Furthermore, as the chlorotoluron-resistant biotypes also survive many other herbicides by cross-resistance (Chauvel, 1992), the resistance genes will certainly persist in the fields even if chlorotoluron selection stops. These newly selected resistances (substituted ureas or phenoxypropanoates resistance), will lead to increasing agronomical problems but without affecting the overall genetic structure of these weed populations.

\section{Acknowledgements}

We thank Dr Darmency for his helpful comments. We also thank Dr S. R. Moss (Rothamsted Station, U.K.), Dr P. Niemann (Institut für Unkrautforschung, Germany) and Dr B. Rubin (Hebrew Jerusalem University, Israel) for providing us with seed samples.

\section{References}

AU MOUEMAR, A. AND GASQUEZ, J. 1983. Environmental conditions and isozyme polymorphism in Chenopodium album L. Weed Res., 23, 141-149.

BISHOP, J. A., HARTLEY, D. J. AND PARTRIDGE, G. G. 1977. The population dynamics of genetically determined resistance to warfarin in Rattus norvegicus from mid-Wales. Heredity, 39, 389-398.

BOSBACH, K. AND HURKA, H. 1981. Biosystematic studies on Capsella bursa-pastoris (Brassicaceae): enzyme polymorphism in natural populations. Pl. Syst. Evol., 137, 73-94.

BROWN, A. H. D. 1979. Enzyme polymorphism in plant populations. Theor. Pop. Biol., 15, 1-42.

CASELEY, J. C., KUEH, J., JONES, O. T. G., HEDDEN, P. AND CROSS, A. R. 1990. Mechanism of chlorotoluron resistance in Alopecurus myosuroides. In: H. Frehse (org.) Abstracts of the Proceedings of the Seventh International Congress of Pesticide Chemistry, p. 417. Hamburg.

CHAuvel, B. 1991. Polymorphisme et sélection pour la résistance aux urées substituées chez Alopecurus myosuroides Huds. Ph.D. Thesis, thèse pour le grade de Docteur en Sciences, Université Paris XI, Orsay.

CHAUvel, B. 1992. Cross resistance to herbicides within a weed (Alopecurus myosuroides Huds.). C. R. C. Soc. Biol., 186, 287-292. 
CHAuvel, B. AND Gasquez, J. 1988. Polymorphisme enzymatique de populations sensibles et résistantes au chlorotoluron chez Alopecurus myosuroides Huds. VIIlème Colloque International sur la Biologie, l'Ecologie et la Systématique des Mauvaises Herbes, 1, 237-246.

CHAUVEL, B., GASQUEZ, J., DOUCEY, M. A. AND PERREAU, F. 1992. Selection for fenoxaprop-ethyl resistance within blackgrass (Alopecurus myosuroides Huds.) populations. IX ème Colloque International sur la Biologie, l'Ecologie et la Systématique des Mauvaises Herbes, 487-496.

DARMENCY, H. AND GASQUEZ, J. 1990. Résistance aux herbicides chez les mauvaises herbes. Agronomie, 6, 457-472.

De PRADO, R., MENENDEZ, J. AND TENA, M. 1991. Response to substituted ureas, triazines and chloroacetanilides in a biotype of Alopecurus myosuroides resistant to chlorotoluron. In: Proceedings of Brighton Crop Conference: Weeds, 1991, pp. 1065-1070. The British Crop Protection Council, Surrey.

GASQUEZ, J. 1985. Breeding system and genetic structure of Chenopodium album populations according to crop and herbicide rotation. In: Jacquard, P., Heim, G. and Antonovics, J. (eds) Genetic Differentiation and Dispersal in Plants, pp. 57-66. NATO ASI Series G:5. Springer Verlag, Berlin.

GASQUEZ, J. AND COMPOINT, J. P. 1981. Isoenzymatic variations in populations of Chenopodium album $\mathrm{L}$. resistant and susceptible to triazines. Agro Ecosystems, 7, 1-10.

GEORGHIOU, G. P. 1990. Overview of insecticide resistance. In: Managing Resistance to Agrochemicals, chap. 2, pp. 18-41. Edited by the American Chemical Society, Washington.

GOTtLiEB, L. D. 1981. Electrophoretic evidence and plant populations. Progr. Phytochem., 7, 1-46.

HAMRICK, J. L., LINHART, Y. B. AND MITTON, J. B. 1979. Relationships between life history characteristics and electrophoretically detectable genetic variation in plants. Ann. Rev. Ecol. Syst., 10, 173-200.

JOHNSSON, H. 1944. Meiotic aberrations and sterility in Alopecurus myosuroides Huds. Hereditas, 30, 469-565.

LEBARON, H. M. 1991. Distribution and seriousness of herbicide resistant weed infestations worldwide. In: Caseley, S. C., Cussans, G. W. and Atkin, R. K. (eds) Herbicide Resistance in Weeds and Crops, pp. 27-44. Butterworth-Heinemann, Oxford

LEROUX, P. 1987. La résistance des champignons aux fongicides. I. Phytoma, 385, 3-35.

LOVELESS, M. D. AND HAMRICK, J. L. 1984. Ecological determinants of genetic structure in plant populations. Ann. Rev. Ecol. Syst., 15, 65-96.

LUMARET, R. 1981. Structure génétique d'un complexe polyploide: Dactylis glomerata L. Ph.D Thesis, thèse de Doctorat d'Etat, Université des Sciences et Techniques du Languedoc, Montpellier.

McNALLY, S., BETTINI, P., SEVIGNAC, M., DARMENCY, H., GASQUEZ, J. AND DRON, M. 1987. A rapid method to test for chloroplast
DNA involvement in atrazine resistance. Plant Physiol., $\mathbf{8 3}, 248-250$.

MALLORY-SMITH, C. A., THILL, D. C. AND DIAL, M. J. 1990. Identification of sulfonylurea herbicide resistant prickly lettuce (Lactuca serriola L.). Weed Technol., 4, 163-168.

MARSHALL, D. R. AND ALLARD, R. W. 1970. Isoenzyme polymorphisms in natural populations of Avena fatua and Avena barbata. Heredity, 25, 373-382.

MENCK, B. H. 1968. Biologie des Ackerfuchsschwanzes (Alopecurus myosuroides Huds.) und seine Verbreitung in Schleswig Holstein. Ph.D Thesis, Inaugural Dissertation zur Erlangung des grades eines Doktors der Landswirtschaft. Albrechts Universität, Kiel.

MIKULKA, J. 1987. Entstehung widerstandfähiger Biotypen von Unkräutern bei langfristiger Anwendung von Herbiziden. Int. Zeitschr. Landw., 1, 59-62.

MOSS, S. R. AND CUSSANS, G. w. 1985. Variability in the susceptibility of Alopecurus myosuroides Huds. (black-grass) to chlorotoluron and isoproturon. Aspect. Appl. Biol., 9, 91-98.

NAYLOR, R. E. L. 1972. Biological flora of the British Isles: Alopecurus myosuroides Huds. (A. agrestis L.). J. Ecol., 60, 611-622.

NIEMANN, P. AND PESTEMER. W. 1984. Resistenz verschiedener Herkünfte von Ackerfuchsschwanz (Alopecurus myosuroides) gegenüber Herbizidbehandlungen. Nachrichtenbl. Deut. Pflanzenschutd., 36, 113-118.

ORNSTEIN, P. A. 1964. Disc electrophoresis. I. Background and theory. Ann. N.Y. Acad. Sci., 121, 321-347.

SOWFFORD, D. L. AND SELANDER, R. B. 1981. BIOSYS-1: a FORTRAN program for the comprehensive analysis of electrophoretic data in population genetics and systematics. J. Hered., 72, 281-283.

WARWICK, S. I. 1991a. The influence of intraspecific variation on the biology of agricultural weeds. In: Proceedings of Brighton Crop Conference: Weeds, 1991, pp.997-1006.

WARWICK, S. I. 1991 b. Herbicide resistance in weedy plants: physiology and population biology. Ann. Rev. Ecol. Syst., 22, 95-114.

WARWICK, S. I. AND BLACK, L. D. 1986. Electrophoretic variation in triazine-resistant and susceptible populations of Amaranthus retroflexus L. New Phytol., 104, 661-670.

WARWICK, S. I. AND BLACK, L. D. 1993. Electrophoretic variation in triazine resistant and susceptible populations of the allogamous weed Brassica rapa. Weed Res., 33, 105-114.

WARWICK, S. 1., THOMPSON, B. K. AND BLACK, L. D. 1987. Genetic variation in Canadian and European populations of the colonizing weed species Apera spica-venti. New Phytol. 105, 301-313.

YAACOBY, T., SCHONFELD, M. AND RUBIN, B. 1986. Characteristics of atrazine-resistant biotypes of three grass weeds. Weed Sci., 34, 181-184

ZHANG, Q. AND ALLARD, R. w. 1986. Sampling variance of the genetic diversity index. J. Hered., 77, 54-55. 